2016

\title{
Geography and Post-phenomenology
}

\author{
Ash, J \\ http://hdl.handle.net/10026.1/5006
}

10.1177/0309132514544806

Progress in Human Geography

SAGE Publications

All content in PEARL is protected by copyright law. Author manuscripts are made available in accordance with publisher policies. Please cite only the published version using the details provided on the item record or document. In the absence of an open licence (e.g. Creative Commons), permissions for further reuse of content should be sought from the publisher or author. 


\title{
Geography and Post-phenomenology
}

[Forthcoming in Progress in Human Geography]

\author{
James Ash \\ Newcastle University \\ james.ash@ncl.ac.uk \\ Paul Simpson \\ Plymouth University \\ paul.simpson@plymouth.ac.uk
}

Please contact the authors before citing 


\section{Abstract}

This paper examines geography's engagements with phenomenology. Tracing phenomenology's influence, from early humanist reflections on the lifeworld to non-representational theories of practice, the paper identifies the emergence of a distinct post-phenomenological way of thinking. However, there is currently no clear articulation of what differentiates post-phenomenology from phenomenology as a set of theories or ideas, nor is there a clear set of trajectories along which such difference can be pursued further. In response to this, the paper outlines three key elements that differentiate phenomenology from post-phenomenology and that require further exploration. First is a rethinking of intentionality as an emergent relation with the world, rather than an a priori condition of experience. Second is a recognition that objects have an autonomous existence outside of the ways they appear to or are used by human beings. Third is a reconsideration of our relations with alterity, taking this as central to the constitution of phenomenological experience given our irreducible being-with the world. Unpacking these differences the paper offers some suggestions as to how post-phenomenology contributes to the broader discipline of human geography.

Key words: Phenomenology; Post-phenomenology; Objects; Materiality; Subjectivity; Intersubjectivity 


\section{Introduction}

This paper examines geography's engagements with phenomenology. Phenomenology is a school of thought that "give[s] a direct description of our experience as it is, without taking account of its psychological origin and the causal explanations which the scientist, the historian or the sociologist may be able to provide" (Merleau-Ponty 2002: vii). Geographers have for some time been interested in phenomenology. Most evidently, this can be seen in the humanistic geographies of the 1970s and 1980s (Buttimer 1976; Buttimer and Seamon 1980; Ley and Samuels 1978a, b). Here, phenomenology, alongside a range of other 'humanistic' approaches, offered an alternative to positivist scientific rationality by developing the "ideas and languages to describe and explain the human experience of nature, space and time" (Buttimer 1976: 278).

Such engagement with phenomenology were subject to a range of critiques around their argued inability to comment on the manipulation of people by objective social forces (Smith 1979), ethnocentrism (Bonnet 1999), and aesthetic masculinity (Rose 1993). However, recently there has been something of a return to phenomenology within geography in light of interests in practice (Simonsen 2004; Thrift 1996), but also specifically under the development of what Rose and Wylie (2006) have called a 'post-phenomenology'. The term postphenomenology first came to prominence through the work of the philosopher of science and technology, Don Ihde (2003). For Idhe (2003) post-phenomenology is an attempt to escape the subject-centered nature of classical phenomenological thought, and, specifically, the transcendental subject or ego found in Husserl. However, geographers have engaged with the term more broadly. As Lea (2009: 373) argues, in the first attempt to anatomise postphenomenogy in geography, this work has re-read phenomenological texts and ideas, often through the lens of post-structural writers such as Gilles Deleuze, Jacques Derrida and Emmanuel Levinas, and, in so doing, has aimed to "extend the boundaries of the phenomenological focus upon the experiencing subject". Drawing together a range of perspectives, Lea (2009: 374) suggests that postphenomenology seeks to:

"expand the realm of what the (experiential) human is, expand the realm of what counts as the empirical field (and how we go about evidencing this), and also what geography is (beginning to rely upon the knowledges amassed in, for example, cognitive science or biomedical disciplines)". 
With this in mind, post-phenomenological work is not straight forwardly poststructural in emphasis, argumentation, or scope. Instead it places a greater emphasis on objects/materiality as opposed to textuality (James 2012). In turn, inspiration has also been found in a range of more recent post-phenomenological authors, such as Michel Henry, Jean-Luc Nancy, Jean-Luc Marion, Bernard Stiegler, and various object-oriented ontologists, who themselves have articulated critical and re-invigorated accounts of phenomenology after poststructuralism.

Based on this, we can identify three interrelated features of this critical relation to phenomenology. First, there has been a move away from the assumption of a subject that exists prior to experience towards an examination of how the subject comes to be in or through experience. Second, this has led to a recognition that objects have an autonomous existence outside of the ways they appear to or are used by human beings (Harman 2002, Meillassoux 2008). Finally, there has been a reconsideration of our relations with alterity in light of these points (Wylie 2009; Rose 2010), taking alterity as central to the constitution of phenomenological experience given our irreducible being-with the world.

In these terms, Lea (2009: 374) argues post-phenomenology "has the potential to refigure our understanding of the relation of the body to the world". However at the same time, Lea recognises that as a distinct area of study, "postphenomenological geographies are...not particularly cohesive" (2009: 377). In what follows we outline a series of key areas that are central to this reengagement with phenomenology through post-phenomenology and suggest how these themes can be pursued to continue a expansive engagement with phenomenological thought. This is not to police this emerging field of enquiry, but to suggest potentially fruitful avenues for further exploration.

\section{Geography and Phenomenology}

The history of phenomenology is highly complex (Moran 2000). For example, Paul Ricoeur argued that "the history of phenomenology is the history of Husserlian heresies" (Zahavi 2006: n.p). This can be explained in at least two ways. Firstly, Husserl significantly revised his phenomenological project, starting from his early critique of psychologism, moving to his descriptive phenomenological investigations of various acts of consciousness, and arriving at his mature transcendental phenomenology (Zahavi 2003). Secondly, a range 
of phenomenologists have taken up Husserl's ideas from across these periods and pushed them in different directions. This variability in what phenomenology actually is, in how it is practiced, and what it ultimately aims towards can also be seen in the many ways it has been drawn on by geographers.

Humanistic geography was the main starting point for geographic engagements with phenomenology (see Buttimer and Seamon 1980; Ley 1979; Ley and Samuels 1978a; Relph 1976; Seamon 1979; Tuan 1977). Here it was felt that the approach of various phenomenologists would facilitate the description of "man's geographical experiences as they are 'actually' experienced - as meaningful, value-laden experience prior to the abstractions of science" (Entrikin 1976: 629). It is important to note, though, that humanistic geography cannot simply be equated with a form of phenomenological geography nor can phenomenology be straightforwardly equated with humanism. Phenomenology did form a key 'rallying call' in the development of humanistic geographies (Pickles 1987). However, a range of other sources of inspiration were also of importance to its development. For example, inspiration was found in Vidal de la Blache's 'Geographie Humaine' (Buttimer 1978), in the existentialism of Sartre and Buber (Samuels 1978), in the social interactionism of Mead (Wilson 1980), and in the epistemological framework offered by pragmatism (Smith 1984) (see Ley 1981). Furthermore, the various versions of phenomenology drawn on by humanistic geographers means that there is also a great deal of diversity here. While for some the writings of Husserl and Heidegger on dwelling and the lifeworld formed a key point of inspiration (Buttimer 1976), for others the more sociological writings of Alfred Schutz on social relations and shared structures of meaning allowed for a greater consideration of the context of everyday life (Ley 1979).

Significant to humanistic geography's engagement with phenomenology was Buttimer's (1976) attempt to understand the human experiences of space by exploring the concept of 'lifeworld'. Key here were Husserl's writings on 'world' and 'reduction', which were also spliced with the more existentialist themes of Heidegger's writings on 'dwelling', Merleau-Ponty's on the body-subject, as well as geographic writing on time-space. The 'lifeworld' refers a shared physical and social world where "experience is constructed" and where consciousness is revealed (Buttimer 1976: 280). Buttimer argued that this lifeworld is generally 'taken-for-granted' with its meaning lying largely unquestioned through our dayto-day routines. Here, phenomenological geography was about questioning such routine interactions with our lifeworld and the alienating influences of science and technology so that we can develop a greater self-awareness and be better able to empathise with the worlds of others. 
Similarly interested in this unthought realm of day-to-day action, though focusing more specifically on Merleau-Ponty's writings, is Seamon's (1979; 1980) influential explorations of spatial experience through the notions of the 'bodysubject' and 'place-ballets'. For Seamon, a phenomenological geography "asks the significance of people's inescapable immersion in a geographical world" (1980: 148). A key facet of this immersion is the everyday movements we engage in in space. Like Buttimer, Seamon emphasized that these movements largely fall into the background of our reflective consciousness. Concentrating on these unthought aspects of spatial experience allowed Seamon (1980: 157) to identify how everyday routine movements operated as 'body-ballets': "a set of integrated behaviors which sustain a particular task or aim". Studying these body-ballets, Seamon argued that space appeared to people through forms of purposeful and sensible embodied action rather than consciously reflected upon cognitive intentions. Seamon then argued for a reconception of what constitutes the human subject through a focus on body-subjects that respond contextually and preconsciously through their sensible actions, rather than mental subjects who cognitively interpret space and then proceeded to act in ways that were based on these cognitive interpretations.

The uptake of phenomenological themes as a part of such humanistic geographies did not take place without critique. Notably here, Pickles (1985) argued that geographers did not engage with the philosophical method of phenomenology in enough detail and so that "Husserl's entire project [was] treated only in caricature form and thus to the empiricist seems to make no sense". While Husserl's project of excavating the transcendental structures of intentional experience undoubtedly presents an immense challenge, a challenge that Husserl himself arguably failed to meet, Pickles suggests that the philosophical motivation and method of phenomenology was largely misunderstood by humanistic geographers. That said, he does suggest a key point from this that was maintained. Namely, that it was impossible to separate subject and object into distinct categories. This resulted in the insight (still argued today by many phenomenologists) that rather than subjects manipulating objects in the external, 'real' physical world we are being in, alongside, and toward the world.

Focusing on this situatedness of the subject has been key to a range of engagements with phenomenology in geography, both within humanistic geography and more recently. Situatedness has, for example, become synonymous with work on 'place' (see Casey 1993; 1997; Relph 1976; Trigg 
2013). As Larsen and Johnson (2012: 633) suggest:

"The insight is that existence is placed: Anything that 'is' first requires a situation to provide both context and horizon for its availability as an object. Place is how the world presents itself; that is to say, being inevitably requires a place, a situation, for its disclosure".

For example, in his foundational work on place Relph (1976: 143) argued that contemporary society was seeing a surge in placelessness, that is "the undermining of the importance of place for both individuals and cultures, and the casual replacement of the diverse and significant places of the world with anonymous spaces and exchangable environments". Notable also is Malpas's (2006) explication of the ways in which place, or placing, is central to Heidegger's concerns with existence or being-there. Heidegger's 'topology' was concerned with how our 'attunement' through moods and embodiment play a central part in the disclosure of the world as we are thrown into it (Larsen and Johnson 2012).

Closely related to this, and constituting another key development in geography's engagement with phenomenological work, are interests in 'dwelling'. For Heidegger, dwelling "names the inflection of space, the twisting and crisscrossing of interiority and exteriority from which both these horizons gain their sense" (Harrison 2007a: 62). Here, subject and world do not pre-exist dwelling but rather come from the 'event' of dwelling (also see Rose 2012). As suggested earlier, this concept did form a key point of interest for humanistic geographers in that it allowed for an emphasis on "an 'ontological vision' of 'togetherness, belonging and wholeness' and so on the discernment of natural 'underlying patterns structures and relationships'" (Seamon 1993: 16 cited in Harrison 2007a: 626). However, in more recent phenomenological inclined geography this 'naturalism' has been contrasted with the promotion of "a radical relationality...and a performative account of existence" (Harrison 2007a: 626). Significant to this latter uptake has often been Ingold's (2000) re-reading of 'the dwelling perspective'. This relational emphasis can be seen in Wylie's (2003: 143) outline of this:

"The dwelling perspective...focuses upon the 'agent-in-its-environment'...as opposed to the self-contained individual confronting a world 'out there'...in focusing upon the 'agent-in-its-environment', upon ongoing, relational contexts of involvement, the dwelling perspective seeks to deny and dispel the tenants of dualistic thought, the separation of...the discursive from the material." 
Dwelling according to Ingold becomes a form of situated "practical absorption" or "wayfinding" in a 'taskscape' (Rose 2012: 759) and Cloke and Jones (2001: 664) suggest that such a notion of dwelling "offers an important acknowledgement of how human actants are embedded in landscapes...[and]...how nature and culture are bound together".

More critically, Harrison (2007a) has expanded the conceptual reach from which understandings of dwelling are developed by contrasting Heideggerian account of dwelling as a proper and self-sufficient mode of being at home in the world (as 'enclosure') with Levinas's account of dwelling as a constitutive openness to the alterity of the other. Here an "irreducible and irresolvable 'relation' to alterity" comes to inherently disquiet any form of dwelling as centripetal movement or assimilation and so positions dwelling only ever as a response to alterity (Harrison 2007a: 635). Arguably this provides a more ethically inclined perspective on the dwelling of people in relation to others.

Recent interests in practice in geography have also entailed an engagement with phenomenological work and this emphasis on our being-in-the-world. For example, Simonsen (2005) draws on Merleau-Ponty's 'sensuous' phenomenology of lived experience to supplement Lefebvre's writings on the body to understand how the body is creative and generative of social-spatial practices (also see Simonsen 2004). Equally, Cresswell (2003) turns to MerleauPonty to rethink landscape beyond its perceived connotations of fixity, towards an understanding based on fluidity and embodied practice. Finally, Merleau-Ponty also provided a foundational reference to Thrift's $(1996$; 1997) articulations of non-representational theory and its interests in the body in practice. Echoing Seamon (1980), Merleau-Ponty's writings provided Thrift (1996: 13) with a means for thinking through how "bodies and things are not easily separated terms" and so how the body is both perceiver and perceived, situated in space-time, and so the point from which we take hold of the world (also see Wylie 2002; 2005).

Humanistic motifs have also re-emerged in some recent engagements with phenomenological ideas, albeit in modified form. For example, there has been a desire to retain a measure of 'minimal humanism' in work interested in themes around affect and practice (see Thrift 2007; Wylie 2010). More extensively, Simonsen (2013) has called for a 'renewed humanism' in human geography. In particular, Simonsen picks up on recent developments around deconstruction and post-/anti-humanism and raises concerns over the ways in which they "demonstrate remaining problems as to the fate of the human in human geography, sometimes even verging on a renewal of geography's old problem of 
naturalism" (2013: 11). Simonsen (2013: 11-12) argues that post-humanist and non-representational accounts have "a troubled relationship to issues of lived experience, notions of subjectivity and agency, and (in...[their]...strongest forms) also to ones of responsibility and politics" given the way these approaches significantly de-centre the subject. In response, Simonson (2013: 12) offers a 'practice-orientated' re-reading of phenomenology (and of Merleau-Ponty in particular) that seeks to provide "a more robust sense of politics, experience and agency". Indeed, Simonsen's re-reading of Merleau-Ponty offers key points that orientate and inform the following sections on the body, intersubjectivity, objects, and the social. As she puts it, Merleau-Ponty already travels "quite a distance down" the anti-/post humanist lane that a number of authors we draw upon are sympathetic to and influenced by (Simonsen 2013: 20). However, at the same time, Simonson's 'new humanism' differs in some significant regards from the post-phenomenology outlined below. In what follows we seek to draw attention to the points of productive connection between these nascent areas of concern as well as important differences and divergences.

Before explicating this further though, it is important to provide some clarification on the term 'post-phenomenology' and how post-phenomenology has been manifest both outside and within geography thus far.

\section{Towards Post-phenomenology}

In his foundational work on post-phenomenology, Idhe seeks to complicate preexisting phenomenological work that begins with an abstract and undifferentated body-subject. In doing so, Ihde (2003: 11) "substitutes embodiment for subjectivity" and moves towards an existential, rather than transcendental, perspective. Ihde considers the body to be a combination of two bodies; a lived body and a socialised body. As Idhe's (2003: 13) argues these bodies are not opposed to one another but exist together:

"first, I deny that body one [the lived] can be absorbed into the cultural, it is the necessary condition for being a body and is describable along the lines of corps vecu [lived body]. But, equally, body one is situated within and permeated with body two [the social], the cultural significations which we all experience. Embodiment is both actional-perceptual and culturally endowed".

While this move is made in light of later work in phenomenology, particularly Merleau-Ponty, Idhe's main post-phenomenological move comes in the 
conversation he sets up between phenomenology, pragmatism, and technoscience. In connecting pragmatism and phenomenology Idhe (2009) employs pragmatism's emphasis on practice to counter the idealist tendencies of phenomenology. This leads to a discussion of practices in terms of "an organism/ environment model rather than a subject/object model" and so "a nonsubjectivistic and interrelational phenomenology" (Idhe 2009: 10-11). However, Ihde does maintain phenomenology's more rigorous style of analysis through its discussions of variation analysis, embodiment, and the lifeworld. From technoscience, Idhe (2009) also folds in an interest in the role technology plays in social and cultural life and how particular technologies can mediate consciousness.

The post-phenomenology that has been tentatively articulated (and actually labeled as such) in geography by Rose and Wylie (2006), Simpson (2009) and Ash (2012) in recent years does share some commonalities with the postphenomenology of Idhe, though a direct influence is by no means evident. The main commonality is a move away from a subject-centered approach to experience. However, while Ihde's work draws upon pragmatist philosophy as a major source of inspiration, geographers often utilise post-structuralist thought in connection with post-phenomenology (see Rose 2006; Wylie 2006). In this engagement with post-structuralism, a key target of the post-phenomenology being developed in geography has been 'intentionality' (Wylie 2006). Intentionality relates to the proposition that an experience is an experience of something - we are always looking at ..., listening to ..., thinking about ..., and so on. This 'aboutness' implicates the presence of an intentional subject in advance of experience. For experience to be 'about' something, there has to be an author of this aboutness and a point from which the directedness of the experience comes. This notion of intentionality is then closely tied to a particular conception of subjectivity whereby the subject governs through "internal representational thought" (Rose 2006: 546). Therefore, the post-phenomenology emerging thus far in geography can be taken most simply to be the development of a phenomenology beyond intentionality (Moran 2000).

This movement away from intentionality does highlight, however, a divergence of the geographical post-phenomenology from the post-phenomenology of Idhe. While Idhe (2007) maintains a faith in the intentional correlate of experience, albeit re-conceptualised in terms of being interrelational (something shared with work in geography on practice), this is not necessarily maintained within the version of post-phenomenology developing in geography. 


\section{Post-Phenomenology and Geography}

Having provided some background to geography's engagement with phenomenology and outlined the development of post-phenomenology, in this section we articulate a series of key themes for a post-phenomenological geography and suggest various trajectories for its future development. These relate to: the body, (inter)subjectivity, objects, and the social.

\subsection{Body}

Central to any post-phenomenology is the body. This is already the most developed of our four themes in existing geographic work. Often cited here are the writings of Merleau-Ponty who argued that there is no ontological separation of the experiencing ' $l$ ' and the body in that "[t]he union of soul and body is not an amalgamation between two mutually external terms" (2002: 102). One is one's body (Morris 2008). The body is "the standpoint from which I must perceive the world...the body cannot itself be understood in an objective, disengaged way" (Gutting 2001: 190). In turn, this body is also intertwined with the world it inhabits (Merleau-Ponty 1968).

Merleau-Ponty's emphasis on a non-dualistic, situated approach to the body has meant his ideas have been drawn on by a range of geographers (see Allen 2004; Cresswell 2003; Davidson 2000; Longhurst 1997; Simonsen 2004; 2013). Equally, his work has informed the development of a post-phenomenology of embodied experience (see Wylie 2002; 2005). Notable here is Wylie's (2006) development of a post-phenomenology of visual self-landscape relations, which draws on Merleau-Ponty's later embodied ontology of the visual. Wylie (2006: 519) rethinks the gazing subject by considering "looking as a perceptual actualisation of landscape and self, or materialities and sensibilities" whereby "the depth of the visible world is the affordance and sustenance of particular senses and perceptions of landscape". Here, landscape is repositioned from being an external inert reality that is seen to naming "the materialities and sensibilities with and according to which we see" (Wylie 2006: 520 [emphasis added]). Therefore, experience is not given to a pre-existing subject, but rather the "body-subject is now 'of' the world: body and world, subject and object, are conjoined as flesh" (Wylie 2006: 525). As such, experience emerges with the world rather than being a product of a subject's directedness towards it. 
However, in developing a post-phenomenology, Merleau-Ponty's writings on the body need to be taken further. As Wylie (2006: 527) notes, one difficulty with Merleau-Ponty's account comes in the fact that "the analysis of 'The Visible and the Invisible' is skeletal and abbreviated". Therefore, Wylie suggests we need to look to other sources for a full understanding of 'how' the perceiving subject/ perceived landscape comes about through the depth of the visual world. Furthermore, critiques have also been made around Merleau-Ponty's articulation of the subject-body-world relation. For example, Michel Serres argues that there is actually a bodilessness to Merleau-Ponty's writings themselves, in that the 'Phenomenology of Perception' contains "Lots of phenomenology and no sensation - everything via language" (Serres and Latour 1995: 131-132).

Similarly, questions can be asked of the agential role of 'world' here. For example, in Seamon's $(1979 ; 1980)$ work on 'place-ballets' there is a clear emphasis on pre-conscious bodily intentionality which substantially expands geographic understandings of what can be included under the heading of 'the human'. However, there is a much more limited discussion of the agency of the 'world' in which such action and movement takes place. The 'dynamism of place' in Seamon's discussion comes primarily from the actions of its human inhabitants rather than from the vibrancy of its non-human components and the material contexts present, which are largely present to be 'manipulated' by the bodysubject. Therefore, post-phenomenology calls for both an emphasis on the vitality of embodied experience, on the dynamism of felt intensities that find corporeal expression in the feeling body, and also an emphasis on the ways in which the body-subject undergoes constant processes of 'affectual composition' in and through its relations with a material-agential world (Seigworth and Gregg 2010).

This account differs from Simonsen's (2013: 22) claim that human agency be considered the "highest form of agency and the type of greatest significance to life on earth". While she recognises this claim is contentious, she also accepts that "if ideas of creating a better world - more human, just and hospitable - are to make sense...[it has]...to be granted existence somehow or other" (2013: 22). Following a post-phenomenological perspective, rather than suggesting that human life and agency be considered in a hierarchical relationship against the non-human, we would argue that the appearance of human life and agency is only ever an outcome gifted to us through a relationship with non-human objects. From the conditions of the atmosphere that made life possible on earth, through to early tools that opened up a temporal horizon in which something like time could be apprehended (see Stiegler 1998), humans exist because of and alongside the non-human, rather than against the non-human. 
One means of thinking through this comes in Michel Henry's (2003) writings on the 'phenomenology of life'. Henry emphasises the phenomenality of life itself, its appearing beyond the phenomenality of intentionality, and suggests that the body's specific mode of appearing is tied to its affectivity. While Husserl argued that subjectivity is a condition of possibility for anything to appear (Zahavi 2003), Henry (2003: 106) argues that:

"our entire existence seems caught in an affective becoming which is not in the least bit indeterminate, ceaselessly oscillating between malaise and satisfaction, suffering and joy - with neutral tonalities like boredom or indifference presenting themselves as a sort of neutralisation of this primitive oscillation".

For Henry (2008: 3), "The phenomenological substance that material phenomenology has in view is the pathetic [felt or passionate] immediacy in which life experiences itself". It is not a case of considering how objects come to appear to consciousness. Rather, this primary affectivity in all appearing, precedes, and so lays the ground for, any sort of appearance to intentionality. For the post-phenomenologist appearance comes before intentionality.

Important here also is that post-phenomenology does not necessarily adopt the anti-technology narrative of much of humanistic geography, in terms of the supposed role of modern technology in standardizing such a 'pathetic' phenomenality of the world. Humanistic geographers often bemoaned the alienating nature of technology in its production of homogenized experiences of place and "anonymous spaces and exchangeable environments" (Relph 1976: 143) and called for the restoration of more authentic "modes of encounter" with place (Seamon 1979: 139). In contrast, post-phenomenogy is more interested in the specific affective phenomenality produced by such technological interventions rather than pre-judging them as appearing in 'deficient' ways or as promoting 'inauthentic' modes of experience (Trigg 2012).

Also though, it is important to note that such vitality and affective composition is not always oriented towards the positive and the expansive. As Henry suggests, affects can be both positive and negative. Drawing attention to a phenomenology of life highlights a fundamental feature of the body's liveliness: its finitude. Drawing on the theme of finitude Harrison (2007b; 2008) has called attention to the need to consider the ways in which the body is susceptible and passive by thinking about embodiment in and through its vulnerability (also see Romanillos, 
2008; 2011). More specifically, Harrison (2008: 427) challenges the predominant notion of such vulnerability being something that is negative and to be overcome and instead sees it as describing "the inherent and continuous susceptibility of corporeal life to the unchosen and the unforeseen - its inherent openness to what exceeds its abilities to contain and absorb". In developing a postphenomenology of the body then, we need to consider passive bodies, those that are sleeping (Bissell, 2009; Harrison 2009) or comfortable (Bissell 2008), as well as those engaged in more active, 'skilled' embodied practices.

\section{2. (Inter)Subjectivity}

A key feature of post-phenomenological writings is their rejection of the lateHusserlian intentional subject that acts as the precondition for the possible appearing of the world in its Cartesian "status as a separate and different region of being" (Zahavi 2003: 51). In seeking to attend to actual lived experience Husserl (2001b) gave the intentional structure of consciousness a central, constitutive position. However, this directedness of perception implies the presence in advance of that experience of a self-grounding, autonomous subject as the source of those intentions. Here, the subject comes first, the world after. By way of contrast, post-phenomenology lays emphasis on perpetual processes of subject formation. This does not present some binary between a passivity and an activity in the sense of a transition from a pre-existent dormant or passive subject that becomes an active subject in the turning of its intentions towards a phenomenon (Husserl 2001a). Rather, there is a more fundamental and ongoing constitution of the subject itself in its embodied being in relation with the world. Ultimately, post-phenomenology seeks to "resituate something which might be still called subjectivity within a pre-symbolic/[pre-]linguistic and material dimension" (James 2012: 13).

This post-phenomenological line can be seen throughout the history of phenomenology after Husserl. We can again return to Merleau-Ponty who sought to modify Husserl's understanding of intentionality by focusing more on the body. For Merleau-Ponty, intentionality expresses "the inextricable unity of world and consciousness, with neither assimilated to the other" (Gutting 2001: 188). Merleau-Ponty sought not to subordinate the 'phenomenological field' to a transcendental subject but rather see the unity of the world as "lived as readymade or already there" (2002: xix). However, there is a danger that MerleauPonty re-installs a human transcendence in his discussion of embodied

subjectivity because his work starts from the subject-object distinction (Hinchliffe 
2003). In Merleau-Ponty's early writing at least, he sets up a subject-object distinction in terms of an object existing only when there is someone to perceive it and, in doing so, maintains the vocabulary of idealism inherited from Husserl (see Merleau-Ponty 1964).

Further, there is a lingering humanism in his later writings on the flesh. As Harman (2005: 173) notes, while "Merleau-Ponty brings humans and nature into reciprocal relation through the flesh of the world", he runs into the problem that "the mutual duel only functions as long as humans are on the scene". This is also reflected in Simonsen's reading of Merleau-Ponty. In Simonsen's words, flesh is the site of: "an interworld - intersubjective and intercorporeal - a vibrant field of consensus and conflict as well as an opportunity for agential capacities" (2013: 22). However, Simonsen's reading of Merleau-Ponty still maintains a key difference between the flesh of the human and the flesh of the world. While human beings flesh is autoaffectionate (it can feel itself feeling), the flesh of the world is not:, the "flesh of the world is not self sensing as our flesh; it is sensible but not sentient. It is still a 'pregnancy of possibilities', but its agency is on another, less productive, plane" (2013: 21, our emphasis).

The term 'less productive' is central here. While the interworld of environment is crucial to the human, it still requires an autoaffectionate human to enable the flesh of the world to appear. In other words, while co-present with the human body, the flesh of the world is always in a subservient relation to the human. Simonsen (2013: 23) argues that a key achievement of thinking the flesh of the world is "a redefinition of agency...[which]...anticipates the notion of the subject as emergent, for which many have looked to more wholehearted anti-humanist approaches". But, if this flesh requires the human in order to appear, then an emergent account of subjectivity still appears rather one sided, being more the product of human capacities than the flesh of the world that appears through these capacities.

Taking this further, we can turn to another phenomenologist writing critically in the wake of Husserl, Jean-Luc Marion (1998). Marion (1998) places the 'givenness' of the world itself as prior to the intentional subject. Rather than the subject playing a constitutive role through the intentional directedness of consciousness towards a perceived phenomenon which it gives unity to, Marion focus on the ways in which the world is given and so the ways in which it has a form of material immanence outside of and prior to any subjective constitution. For Marion (1998: 3) "Givenness alone is absolute, free and without condition precisely because it gives". As such, the subject is in fact only ever an outcome 
of this givenness, not its source. The appearing of the world, its absolute and anonymous giveness without giver, is primary over any intentionality or sense constitution (James 2012).

This sort of rethinking of the subject also asks the question: "where does this leave "us"? If in such work there has been a move to understand the subject as an 'appearing-with' that arises in the body's being-in-relation-with other bodies and objects (Critchley 1999), this raises a number of questions about how we can understand intersubjective relations. It is no longer simply a case of considering our sharing of 'meaning contexts' with like-minded individuals as opposed to those that are different from us (Ley 1979). And, this 'social' (as we argue later) presents us with a somewhat more diverse field in relation to which we might consider such relation. In addition to the societal structures that action takes places within (Ley 1981; Pickles 1987), what implications do the multitude of vibrant materials that we might engage with have for understanding such intersubjectivity? Ultimately, how do we account for what remains of the intersubjective when any such subject entering into a relation has already been decentred amid the givenness of the world and so cannot form the foundation or origin of that relation to be built upon?

Post-phenomenological work in geography has largely responded to these questions in terms of alterity. For example, Wylie (2009) has sought to re-figure the relationship between self and landscape in terms of absence and noncoincidence. Wylie (2009) critiques phenomenology's 'metaphysics of presence' its emphasis on sharing, commonality, entwinement, auto-affection - by suggesting that we are constitutively haunted by an exposure to what is other. Here we are formed by a 'constitutive fissure' which "forbids phenomenological fusion of self and world" and "entails a simultaneous opening-onto and distancing-from" alterity (Wylie 2009: 285). Furthermore, Rose (2006) has outlined what he calls 'dreams of presence' which mark both an imagination of, and movement toward, presence and so the self-presence of the subject (see Rose, 2006; 2010; Wylie 2010). This decenters the subject in that presence is impossible, existing only as a possibility that is held out to us "at the horizon of our being" (Rose 2006: 542). In being dreamt of, such dreams of presence are only ever moved toward and so presence, in the form of a subject's certitude, is "always-already receding" (Rose 2006: 545).

There are, however, further lines of thinking to be pursued. One alternative that arguably comes without the same onto-theological baggage as Derrida and Levinas's work is the writings of Jean-Luc Nancy. Nancy (2000) suggests that the 
relations between body-subjects can be thought in terms of what he calls the 'presencing' of our being-with one another (Simpson forthcoming). Here Nancy gives primacy to the relation, not to alterity. As Nancy (2000: 34) states:

"what is at stake is no longer thinking:

- beginning from one, or from the other,

- beginning from their togetherness, understood now as the One, now as the Other,

- but thinking, absolutely and without reserve, beginning from the 'with', as the proper essence of one whose Being is nothing other than with-one-another".

In this sense the relation is contemporaneous with its terms; the subject is not present beforehand nor is it really ever a finished product of the relation. While this might suggest some sort of reciprocity or sameness between self and other, the inherent movement of 'dis-position' in presencing forestalls this. As the subject approaches itself, it is already moving away from itself; Nancy emphasises the dis- of dis-position to imply a perpetual process of presentation and withdrawal whereby "[w]e are each time an other, each time with others" (Nancy 2000: 35).

Ultimately, a post-phenomenological account of subjectivity and intersubjectivity involves developing and maintaining the idea that the subject is not the secure foundation from which our understanding of the world and others is to be gained or "the basis or fount of intelligibility" (Anderson and Wylie 2009: 323). It is possible though to develop accounts of how both self and world and self and other perpetually devolve from their co-constitutive being-with each other. In this account, the world is not reduced to the operations of the Husserlian subject's constitutive mental acts of 'appresentation' (as "the process whereby the direct perceptual presentation of one object mediates or makes possible the indirect perception of certain other aspects of that object that are themselves inaccessible to direct perception" (Sanders 2008: 143)) or 'pairing' (as the connection made "when one object is regularly presented - thereby 'associated' with another" (Sanders 2008: 143)). Rather there is a co-appearence and disposition of self with self, self with other, and self with world.

\subsection{Objects}

Much has been written in geography about the nature and status of materiality (Anderson and Wylie 2009; Jackson and Fanin 2011). These accounts are often based upon the idea of relationality. As Anderson and Wylie argue: 
"heterogeneous materialities actuate or emerge from within the assembling of multiple, differential, relations and...the properties and/or capacities of materialities thereafter become effects of that assembling" (2009: 320).

Here, objects are understood to be surface effects, or accruals of multiple sets of relations that precede or enable particular things to exist. The outcome of this type of relational thinking is that there is now a suspicion of terms such as 'object' or 'thing' that previous forms of phenomenology have used to describe matter (Heidegger 1977). However, this call to examine materiality as relation in geography has resulted in accounts of world that appear more and more divorced from a human being's experience of this world (Simonsen 2013). As Morton argues, humans (and indeed all other types of entity) experience objects as objects, rather than some assemblage or actualisation of hetereogenous materials. In his words: "there is no such thing as matter. I've seen plenty of entities...: photographs of diffusion cloud chamber scatterings, drawings of wave packets, iron filings spreading out around a magnet. But l've never seen matter" (Morton 2013: 42, also see Harman 2010a; 2010b). In engaging understandings of materiality, a post-phenomenological geography argues for a reinvigorated account of objects and suggests that objects present a starting point for analysis.

The stimulus for Morton's point around the primacy of objects over matter or relations is the emergence of object-orientated ontology (OOO), a development that has also begun to have some influence in geography when it comes to thinking about agency and affectivity (Shaw 2012; Shaw and Meehan 2013; Meehan et al 2013). For Bogost:

"OOO puts things at the center of being. We humans are elements, but not the sole elements, of philosophical interest...In contemporary thought, things are usually taken either as the aggregation of even smaller bits (scientific naturalism) or as constructions of human behavior and society (social relativism). 000 steers a path between the two, drawing attention to things at all scales...and pondering their nature and relations with one another as much with ourselves" (2012: 6).

While work in OOO offers multiple accounts of what objects are (compare Bogost 2012; Morton 2012; Bryant 2011; Harman 2010b), it accepts that objects are independent and autonomous units that cannot be reduced to a sum of relations that compose them. This is not a return to an essentialist account of objects as substances with properties, nor an anthropocentric account of objects as slaves 
or tools of the human beings that put them to use. In fact, quite the opposite. Whereas a material account of objects assumes objects are relational compositions of matter, Bogost argues that objects are autonomous units that only ever partially meet. In this case, objects do not simply contact and interact with one another in a way that is determined by their pre-existent or emergent properties. Instead they selectively encounter one another, producing a caricature:

"objects try to make sense of each other through qualities and logics they possess. When one object caricatures another, the first grasps the second in abstract, enough for the one to make sense of the other given its own internal properties. A caricature is a rendering that captures some aspects of something else at the cost of other aspects" (Bogost 2012: 66).

As such, objects only disclose some of their qualities, depending on what they encounter.

From this perspective, post-phenomenology allows us to consider how objects have capacities for relation that humanistic forms of phenomenology would only assign to human beings. This is not to eliminate or downgrade the status of the human, as Simonsen (2013) fears, but rather to elevate the status of objects and accept that they encounter the world through similar structures (if not capacities) as phenomenology argues human beings do. As Morton suggests, interaction between objects is not a brute form of causality, but the same kind of aesthetic event as when a human might perceive that object. In his words:

"causality is wholly an aesthetic phenomenon. Aesthetic events are not limited to interactions between humans or between humans and painted canvases or between humans and sentences in dramas. They happen when a saw bites into a fresh piece of plywood. They happen when a worm oozes out of some wet soil" (2013: 19).

Recognising that causality is aesthetic de-centres and troubles phenomenological accounts of the object as either a set of relations or as a tool. For geographers, this extends a phenomenological analysis to incorporate and study non-human things. By taking the autonomy of objects seriously, postphenomenology can begin to investigate relations between non-human objects, without reducing these relations to how they appear to human beings (see Ash 2013). 


\subsection{The Social}

Questions regarding 'the social' when it comes to work influenced by phenomenology in geography are not new (see Ley 1978). To return to MerleauPonty one final time, one aspect of our embodied existence that Merleau-Ponty's work arguably does not pay enough attention to is the way in which our bodies are socialised into a specific comportment and does not adequately account for the ways in which the body is performatively interpolated within broader societal framings (Hass 2008). While Merleau-Ponty (2002) does talk of the interrelation of the biological and the personal in terms of the formation of habit or the relation between the sedimented and spontaneous, he has little or no recognition that "culture coerces our bodies in a political way" (Hass 2008: 94).

From a post-phenomenological perspective, what remains of 'the social' understood through categories such as age, gender and race? This is an important question. As Colls (2012) argues, phenomenology is often guilty of presenting an undifferentiated body-subject. In its place she suggests a model of difference "that is not pre-given, hierarchical or oppositional" (Colls 2012: 441). Here difference is not a matter of categorical differentiation but as a "question whose potential is still yet to be fully known" (2012: 438). Taking this open and corporeal sense of difference into account, a post-phenomenology might advocate that these categories are not simply social constructions or the products of particular discourses or power relations, but what Colls, drawing upon Grosz (2005), calls forces (or what we have been calling objects). Such forces:

"operate at a range of scales and intensities. They can pass through and inhabit bodies (metabolism, circulation, ovulation, ejaculation), they are intangible and unknowable and yet are sometimes felt by the body and travel between bodies (fear, hope, love, wonder, hate, confidence) and they are produced by and active in the constitution of wider social, economic and political processes" (Colls 2012: 439).

From this perspective, social differences are real in the sense that they have a presence and force that is irreducible to discourse or social context. The power of these categories comes from how the singularity of objects and their forces in the world are transmitted through and across populations of humans, but also nonhumans. Age, gender, and race might be understood as corporeal embodiments of what Stiegler terms social facts, transmitted via 'tertiary retentions':

"The memory of the human entity is essentially exteriorised, materialised and 
spatialised. It is spatially, materially and technically projected into what is constituted as a common space and time, projected if not out of time then at least beyond its own original temporality and in a certain way put into reserve in space, enabling it to become at once the memory of the individual and of the group" (2012: 13).

Here, objects become platforms for and inscriptions of memory. As Morton argues, both human and non-human "memories are inscribed on an object-like surface, of the body or of some more general unconscious, either locally or nonlocally" (2013: 1808). Following our earlier discussion of aesthetic causality, and recognising that by object we mean things like air or light as much as brains or computers, these kinds of memory can be understood as sensual translations or partial comprehension of other objects retained by the objects that are involved in an encounter. Indeed, Simonson gestures towards a similar account of the social as somatic and retentional when she writes that:

"Emotional meanings are 'secreted' in bodily gestures in the same way that musical/ poetic meaning is 'secreted' in a phrase of a sonata or a poem. These meanings are communicated and 'blindly' apprehended through corporeal intentions and gestures that reciprocally link one body to another. Emotional experience is something public and 'in-between'- situated in the perceptibility of bodily gestures". (2013: 17).

Culture or race are then what is selectively retained through different encounters between a variety of objects, such as words, images and bodies, that make up the identifiable aspects of that culture. As Thrift argues in relation to learning to write Chinese characters:

"The sheer effort involved in learning Chinese characters by writing the characters over and over again (in distinction to learning alphabetic systems, which require much less writing input) coupled with the traditional system of learning itself, which often begins with 'writing in the air"... means that words are remembered as gestures and so written into the body through movement as much as vision. This kinetic etching activates both hemispheres of the brain, and, in particular, those parts of it which involve motoric memory skills" (2009: 135).

In this case, learning to write Chinese characters involves the retention and transmission of memory between different objects, whereby particular shapes of line become translated into gestural movements in the limbs of the body and then, in turn, translated into electrical signals in the brain and vice-versa. These 
selective encounters in turn constitute Chinese as a shared language.

This account of the social as a selective encounter between objects can be understood as a further development of Luce Irigaray's work on air and her critique of 'ground' that, she argues, dominates phenomenological analyses of bodily existence. For Irigaray air is the: "unthinkable that exceeds all declaration, all saying. Or posing, phenomenon, or form. While remaining the condition of possibility, the resource, the groundless ground" (1999: 5). Or in other words: "air would be the forgotten material mediation of the logos. Eluding both the sensible and the intelligible, it would permit their very determination as such" (Irigaray 1999: 11). Here air presents a metaphor for understanding the circulation of human and non-human objects as they selectively encounter one another and act as the conditions of possibility for the transmission of sense. Forces such as air or light can also be understood as some of the actual mediums through which the potentials for human memory (and thus the production of social 'facts' such as age, class or gender) are transmitted in ways that are transparent, unreflected upon and often implicit to a situation (such as the soundwaves produced by a voice or musical instrument, see Ash, 2014, Simpson 2009).

Expanding the concept of retention in this way challenges humanist understandings of the social as a field of bodily sedimentation. For Simonsen (2013: 16-17), this sedimentation is based around the reversibility of the body in that "Body-subjects are visible-seers, tangible-touchers, audible listeners, etc., enacting an ongoing intertwining between the flesh of the body, the flesh of others and the flesh of the world". While Simonsen recognises that reversibility can take place in relation with the world as well as other people, ultimately the body's reversibility enables sociality to happen and, in doing so, operates as the receptacle that receives or incorporates social sediment into it. Taking Irigaray's account of air seriously would suggest that the human body is not the site at which sociality is generated or retained, but only one node in an ongoing circulation of objects that do not need to be perceived by the human body to have particular social effects. The social is then literally constructed by the objects that surround, pass over, miss and engulf human bodies in an often contingent manner, and which is not necessarily orientated around the concerns or projects of those involved in the social field.

\section{Conclusions}

The sources we have drawn together under the banner of 'post-phenomenology' 
emerge from a variety of intellectual traditions and in many cases utilise different onto-epistemological assumptions about the world that by no means fully coincide. However, we believe there is a cohesion that underlies these differences. To conclude, we want to draw attention to these points of cohesion and summarise how a post-phenomenology draws upon, while is clearly different from, existing modes of phenomenological investigation and theory. By emphasising the differences between phenomenology and post-phenomenology, we also offer some suggestions as to how post-phenomenology contributes to human geography more broadly as a discipline.

The first major cohesion among the ideas discussed here is a commitment to overcoming the human-world, subject-object correlate and, in doing so, unsettling the intentional correlate of experience. While a variety of phenomenological thinkers claim to overcome the subject-object problem, they actually just sidestep the problem by suggesting that no distinction between subject and object can be fully made. However, this is actually a return to an idealism in which things in the world are granted existence, but only by the humans that perceive them and only through exclusively human structures of concern and familiarity. Postphenomenology takes a different approach in a number of ways. For example, instead of seeing the subject as directing its attentions toward a world in terms of an intentional, and so sense-bestowing, directedness, some strands of postphenomenology are more concerned with the ways in which self and world, or objects themselves, devolve or appear in the relations they enter into. Rather than starting with a subject and object correlate (where the subject is ultimately the primary term), we are to start with the relations themselves (Nancy 2000), or the givenness of the world itself (Marion 1998), and treat anything that appears as secondary to this fundamental implication/givenness. Taking this further, other strands of post-phenomenology recognise the autonomous existence of the world outside of the ways that it appears to humans and so approaches "determinate objects that exist both in and out of contact" (Harman 2012: 106, our emphasis). These developments provide a tool kit for interrogating the world in its very alterity. By theorising such appearance and objects one can begin to rethink seemingly 'social' constructions such as gender or race as actual constructions brought about by encounters between different human and nonhuman objects.

A (re)turn to objects as the basic unit of analysis also sounds a note of caution over geographers enthusiastic turn to terms such as matter and materiality to understand the 'stuff' of life. While terms such as matter seem to be helpful in emphasising a world of dynamic change and emergence, these terms can 
become no more than a generalised metaphor that ignores the objects that actually appear in a given moment. Similar to Harrison's comments on the term 'relationality', the term materiality "risks becoming simply a matter of a quantitatively expanded sociospatial imaginary rather than a shift towards the appreciation of intervallic topologies, complex figures, and diverse phrases and regimens" (2007b: 590). Indeed, when emphasising matter and materiality, the specific qualities of objects that geographers are studying can disappear and so it becomes hard to understand the motivation behind why people do things or why events unfold in a particular way. For example, relational approaches to consumption may only consider the desire to consume various goods as the outcome of connections between advertising, marketing, and consumption objects. However, in doing so, this approach would ignore what it feels like to wear a pair a Nike's over a pair of Reebok's and what is alluring about these objects in the first place.

The second point of cohesion is that post-phenomenology recognises that much of the phenomenon known as 'human consciousness' does not take place 'in' the bodies of the human, but 'with' the dense scaffolding of things that enable and shape human thought (Hutchins 1996). The result of this is that human politics and sociality has to be a politics and sociality of the non-human. The capacity to express and communicate thought is enabled and transmitted via exterior objects. The sense of the world does not appear from a source external or transcendent to the world, nor from within those objects themselves, but perpetually from the unfolding of the their interrelations in the playing out of the world (Nancy 1997). The transmission of language, the very basis of political expression, cannot be separated from the specificity of the objects through which language is made. A post-phenomenology encourages an interrogation of these objects in ways that does not reduce them to simple tools that humans use to complete pre-existing aims and goals.

More speculatively, for geography, post-phenomenology's emphasis on beingwith rather than a more solitary being-there points to the ecological embeddedness of human beings - with a whole range of 'others' - and can help deal with the politics of non-human relations. As Clark (2011) argues, environmental change and ecological disasters are as much a problem for the world we live in as identity politics and social inequality. If objects encounter the world through similar structures as human beings, then post-phenomenology becomes an expanded project that allow us to study non-humans both in and outside of their relation with the human. Yusoff suggests that studying nonhumans requires a concept of the insensible, which is: 
"the agitation, the provocation, the curiosity, the desire that draws out the work of intelligibility, that makes us practice politics as writing, thinking, and practicing with others, in order to bring to sense that which we know, but do not know" (2013: 213).

Post-phenomenology and its concern with objects allows us to move beyond curiosity or provocation to begin to think the aesthetic causalities of how objects relate to one another and explore what non-human things are and what they do in ways that attends to these things as objects, rather than relations or processes.

In summation, post-phenomenology is not about abandoning the key insights of phenomenology. Instead it is about refiguring and expanding phenomenology's analytic and conceptual boundaries. It is about exploring, what Quentin Meillassoux (2009) terms 'the great outdoors' - an excessive world that lies outside of the human-environment correlate, but which is central to shaping human capacities, relations and experiences.

\section{References}

Allen, C. (2004) Merleau-Ponty's phenomenology and the body-in-space encounters of visually impaired children. Environment and Planning D: Society and Space, 22, 719-735.

Anderson, B. and Wylie, J. (2009) On geography and materiality. Environment and Planning A, 41, 318-335.

Ash, J. (2012) Technology, Technicity and emerging practices of temporal sensitivity in videogames. Environment and Planning A, 44(1), 187-203.

Ash, J (2013) Rethinking Affective Atmospheres: Technology, perturbation and space times of the non-human. Geoforum, 49(2), 20-28.

Ash, J. (2014) Technology and Affect: Towards a theory of inorganically organised objects. Emotion, Space and Society, http://dx.doi.org/10.1016/ j.emospa.2013.12.017

Bissell, D. (2008) Comfortable bodies: sedentary affects. Environment and 
Planning A, 40, 1697-1712.

Bissell, D. (2009) Vulnerable quiescence: mobile timespaces of sleep. Cultural Geographies, 16, 427-445.

Bogost, I. (2012) Alien Phenomenology, or what it's like to be a thing. Minnesota University Press, Minneapolis.

Bonnett, A. (1999) White Identities. Prentice Hall, Harlow.

Bryant, L. (2011) The Democracy of Objects. Open Humanities Press, Ann Arbor.

Buttimer, A. (1976) Grasping the Dynamism of the Lifeworld. Annals of the Association of American Geographers. 66(2) pp. 277-292.

Buttimer, A. (1978) Charism and Context: The Challenge of La Geographie Humaine. In Ley, D. and Samuels, M. S. (eds) Humanistic Geography: Prospects and Problems. Croom Helm, London.

Buttimer, A. and Seamon, D. (eds) (1980) The Human Experience of Space and Place. Croom Helm, London.

Casey, E. (1993) Getting back into place: Toward a renewed understanding of the place-world. Indiana University Press, Bloomington.

Casey, E. (1997) The fate of place: A philosophical history. University of California Press, Berkeley.

Clark, N. (2011) Inhuman Nature: Sociable Life on a Dynamic Planet. Sage Publishing, London.

Cloke, P. and Jones, O. (2001) Dwelling, place, and landscape: an orchard in Somerset. Environment and Planning A, 33, 649-666.

Colls, R. (2012) Feminism, bodily difference and non-representational geographies Transactions of the Institute of British Geographers, 37 (3) pp. 430445 .

Cresswell, T. (2003) Landscape and the Obliteration of Practice. In Anderson, K., Domosh, M., Pile, S. and Thrift, N. (eds.) Handbook of Cultural Geography. Sage, 
London.

Critchley, S. (1999) Ethics-Politics-Subjectivity: Essays on Derrida, Levinas, and Contemporary French Thought. London, Verso.

Davidson, J. (2000) A phenomenology of fear: Merleau-Ponty and agoraphobic life-worlds. Sociology of Health and IIIness, 22, 640-660.

Entrikin, J. N. (1976) Contemporary Humanism in Geography. Annals of the Association of American Geographers, 66, 615-632.

Grosz, E. (2005) Time travels: feminism, nature, power. Allen and Unwin, Crows Nest.

Gutting, G. (2001) French Philosophy in the Twentieth Century. Cambridge University Press, Cambridge.

Harman, G. (2002) Tool Being. Open Court, Chicago.

Harman, G. (2005) Guerrilla Metaphysics. Open Court, Chicago.

Harman, G. (2010a) I am also of the opinion that materialism must be destroyed Environment and Planning D: Society and Space 28(5) 772 - 790.

Harman, G. (2010b) Towards Speculative Realism. Zero Books, London.

Harman, G. (2012) On Interface: Nancy's Weights and Mases. In Gratton, P. and Morin, M-E. (eds) Jean-Luc Nancy and Plural Thinking: Expositions of World, Ontology, Politics, and Sense. SUNY Press, New York.

Harrison, P. (2007a) The space between us. Opening remarks on the concept of dwelling. Environment and Planning D: Society and Space, 25, 625-647.

Harrison, P. (2007b) 'How shall I say it?' Relating the non-relational. Environment and Planning $A$, 39, 590-608.

Harrison, P. (2008) Corporeal Remains. Vulnerability, proximity and living-on after the end of the world. Environment and Planning A, 40, 423-445.

Harrison, P. (2009) In the absence of practice. Environment and Planning D: 
Society and Space, 27, 987-1009.

Hass, L. (2008) Merleau-Ponty's Philosophy. Indiana University Press, Indianapolis.

Heidegger, M. (1977) The Question concerning Technology. Harper Collins Books, New York.

Henry, M. (2003) Phenomenology of Life. Angelaki, 8(2), 97-110.

Henry, M. (2008) Material Phenomenology. Fordham University Press, New York.

Hinchliffe, S. (2003) 'Inhabiting' - Landscape and Natures. In Anderson, K., Domosh, M., Pile, S. and Thrift, N. (eds.) Handbook of Cultural Geography. Sage, London.

Husserl, E. (2001a) Analyses concerning passive and active synthesis. Kluwer Academic Publishers, London.

Husserl, E. (2001b) Logical Investigations: Volume 1. Routledge, London.

Hutchins, E. (1996) Cognition in the Wild. MIT Press, Cambridge.

Idhe, D. (2003) Postphenomenology - again? Working Paper No. 3: Centre for STS Studies, Aarhus University Denmark, 3-25.

Idhe, D. (2007) Listening and Voice: Phenomenologies of Sound. SUNY Press, Albany.

Idhe, D. (2009) Postphenomenology and Technoscience. SUNY Press, Albany

Ingold, T. (2000) Perception of the Environment: Essays in Livelihood, Dwelling and Skill. Routledge, London.

Irigaray, L. (1999) The Forgetting of Air in Martin Heidegger. University of Texas Press, Texas.

Jackson, M and Fanin, M. (2011) Letting Geography fall where it may aerographies address the elemental. Environment and Planning D: Society and 
Space 29, 435-444.

James, I. (2012) The New French Philosophy. Polity, Cambridge.

Larsen, S. C. and Johnson, J. T. (2012) Toward an open sense of place: phenomenology, affinity, and the question of being. Annals of the Association of American Geographers, 102(3), 632-646.

Lea, J. (2009) Post-phenomenological geographies. In Kitchen, R. and Thrift, N. (eds.) International Encyclopedia of Human Geography. Elservier, London.

Ley, D. (1978) Social Geography and Social Action. In Ley, D. and Samuels, M. S. (eds.) Humanistic Geography: Prospects and Problems. Croom Helm, London.

Ley, D. (1979) Social Geography and the Taken-For-Granted World. In Gale, S. and Olsson, G. (eds) Philosophy in Geography. D. Reidel Publishing Company, London.

Ley, D. (1981) Cultural/humanistic geography. Progress in Human Geography, 5, 249-257.

Ley, D. and Samuels, M. S. (eds.) (1978a) Humanistic Geography: Prospects and Problems. Croom Helm, London.

Ley, D. and Samuels, M. S. (1978b) Introduction: Contexts of Modern Humanism in Geography. In Ley, D. and Samuels, M. S. (eds.) Humanistic Geography: Prospects and Problems. Croom Helm, London.

Longhurst, R. (1997) (Dis)embodied geographies. Progress in Human Geography, 21, 486-501.

Malpas, J. (2006) Heidegger's topology: Being, place, world. The MIT Press, Cambridge MA.

Marion, J-L. (1998) Reduction and Givenness: Investigations of Husserl, Heidegger and Phenomenology. Northwestern University Press, Evanston.

Meehan, K, Shaw I and Marston, S (2013). 'Political Geographies of the Object', Political Geography, http://dx.doi.org/10.1016/j.polgeo.2012.11.002 
Meillassoux, Q. (2008) After Finitude: An Essay on the Necessity of Contingency. Continuum, Newyork.

Merleau-Ponty, M. (1964) The Primacy of Perception. North Western University Press, Evanston.

Merleau-Ponty, M. (1968) The Visible and the Invisible. North Western University Press, Evanston.

Merleau-Ponty, M. (2002) Phenomenology of Perception. Routledge, London.

Moran, D. (2000) Introduction to Phenomenology. Routledge, London.

Morris, D. (2008) Body. In Diprose, R. and Reynolds, J. (eds.) Merleau-Ponty: Key Concepts. Acumen, Stocksfield.

Morton, T. (2012) The Ecological Thought. Harvard University Press, Massachusetts.

Morton, T. (2013) Realist Magic: Objects, Ontology, Causality. Open Humanities Press, Michigan.

Nancy, J-L, (1997) The Sense of the World. University of Minnesota Press, London.

Nancy, J.-L. (2000) Being Singular Plural. Stanford University Press, Stanford.

Pickles, J. (1985) Phenomenology, science and geography. Cambridge University Press, Cambridge.

Pickles, J. (1987) Geography and Humanism. Geo Books, Norwich.

Relph, E. C. (1976) Place and Placelessness. Pion, London.

Romanillos, P. (2008) "Outside it is snowing": experience and finitude in the nonrepresentational landscapes of Alain Robbe-Grillet, Environment and Planning D: Society and Space, 26: 795-822.

Romanillos, P. (2011) Geography, Death and Finitude. Environment and Planning 
A, 43: 2533-2553.

Rose, G. (1993) Feminism and Geography. Polity Press, Cambridge.

Rose, M. (2006) 'Gathering dreams of presence': A project for the cultural landscape. Environment and Planning D: Society and Space, 24, 537-554.

Rose, M. (2010) Back to back: a response to Landscape, absence and the geographies of love. Transactions of the Institute of British Geographers, 35, 141-144.

Rose, M. (2012) Dwelling as marking and claiming. Environment and Planning D: Society and Space, 30(5), 757-771

Rose, M. and Wylie, J. (2006) Animating Landscape. Environment and Planning $D$ : Society and Space, 24, 475-479.

Samuels, M. S. (1978) Existentialism and Human Geography. In Ley, D. and Samuels, M. S. (eds.) Humanistic Geography: Prospects and Problems. Croom Helm, London.

Sanders, M. (2008) Intersubjectivity and alterity. In Diprose, R. and Reynolds, J. (Eds.) Merleau-Ponty: Key Concepts. Acumen, Stocksfield.

Seamon, D. (1979) A Geography of the Lifeworld. St. Martin's Press, New York.

Seamon, D. (1980) Body-Subject, Time-Space Routines, and Place-Ballets. In Buttimer, A. and Seamon, D. (eds.) The Human Experience of Space and Place. Croom Helm, London.

Seigworth, G. J. and Gregg, M. (2010) An Inventory of Shimmers. In Gregg, M. and Seigworth, G. J. (eds.) The Affect Theory Reader. Duke University Press, London.

Serres, M. and Latour, B. (1995) Conversations on Science, Culture, and Time: Michel Serres with Bruno Latour. University of Michigan Press, Ann Arbor.

Shaw, I. G. R. (2012) Towards an Evental Geography. Progress in Human Geography, 36(5), 613-627. 
Shaw, I. G. R. and Meehan, K. (2013) Force-full: power, politics and objectoriented philosophy. Area, 45(2), 216-222.

Simonsen, K. (2004) Spatiality, Temporality and the Construction of the City. In Baerenholdt, J. O. and Simonsen, K. (eds.) Space Odysseys: Spatiality and social relations in the 21st Century. Ashgate, Aldershot.

Simonsen, K. (2005) Bodies, Sensations, Space and Time: The Contribution from Henri Lefebvre. Geografiska Annaler. Series B. Human Geography, 87(1),1-14.

Simonsen, K. (2013) In quest of a new humanism: Embodiment, experience and phenomenology as critical geography, Progress in Human Geography 37(1) 10-26.

Simpson, P. (2009) 'Falling on deaf ears': a post-phenomenology of sonorous presence. Environment and Planning A, 41, 2556-2575.

Simpson, P. (forthcoming) What remains of the intersubjective?: on the presencing of self and other. Emotion, Space and Society.

Smith, N. (1979) Geography, Science, and Post-Positivist Modes of Explanation. Progress in Human Geography, 3, 356-383.

Smith, S. (1984) Practicing Humanistic Geography. Annals of the Association of American Geographers, 74(3), 353-374.

Stiegler, B. (1998) Technics and Time 1: The Fault of Epimetheus. Stanford University Press, California.

Stiegler, B. (2012) Relational Ecology and the Digital Pharmakon, Culture Machine, 13, pp. 1-19.

Thrift, N. (1996) Spatial Formations. Sage, London.

Thrift, N. (1997) The Still Point. In Pile, S. and Keith, M. (eds.) Geographies of Resistance. Routledge, London.

Thrift, N. (2007) Non-Representational Theory: Space, Poltics, Affect. Routledge, London.

Thrift, N. (2009) Different atmospheres: of Sloterdijk, China and site, Environment 
and Planning D: Society and Space, 27, 119-138.

Trigg, D. (2012) The Memory of Place: A Phenomenology of the Uncanny. Ohio University Press, Athens.

Tuan, Y-T. (1979) Space and Place: The Perspective of Experience. University of Minnesota Press, London.

Wilson, B. M. (1980) Social Space and Symbolic Interaction. In Buttimer, A. and Seamon, D. (eds) The Human Experience of Space and Place. Croom Helm, London.

Wylie, J. (2002) An essay on ascending Glastonbury Tor. Geoforum, 33, pp 441-454.

Wylie, J. (2003) Landscape, performance and dwelling: a Glastonbury case study. In Cloke, P. (ed) Country Visions. Pearson, Harlow.

Wylie, J. (2005) A single day's walking: narrating self and landscape on the South West Coast Path. Transactions of the Institute of British Geographers, 30, 234-247.

Wylie, J. (2006) Depths and folds: on landscape and the gazing subject. Environment and Planning D: Society and Space, 24, 519-535.

Wylie, J. (2009) Landscape, absence and the geographies of love. Transactions of the Institute of British Geographers, 34, 275-289.

Wylie, J. (2010) Non-representational subjects? In Anderson, B. and Harrison, P. (eds.) Taking-Place: Non-Representational Theories and Geography. Ashgate, Farnham.

Wylie, J. (2010) Shifting grounds: a response to Mitch Rose. Transactions of the Institute of British Geographers, 35, 145-146.

Yusoff K. (2013) Insensible worlds: postrelational ethics, indeterminacy and the (k)nots of relating Environment and Planning D: Society and Space 31(2) 208 226.

Zahavi, D. (2003) Husserl's Phenomenology. Stanford University Press, 


\section{Stanford.}

Zahavi D. (2006) Does (Husserlian) Phenomenology have a Future? Available from: http://www.newschool.edu/nssr/husserl/Future/Part\%20Two/Zahavi.html. Accessed on $07 / 02 / 14$. 